Nadiia Fisunenko,

Postgraduate Student,

Department of International Economic Relations, Regional Studies and Tourism, University of Customs and Finance,

Dnipro, Ukraine

\title{
Marketing determinants of the development of the investment market: innovations in the assessment of demand and supply (case study for the construction industry)
}

The article is devoted to development of methodological bases of revitalization of functioning of the investment market. The basic marketing determinants for the development of investment market, including supply and demand of investment resources are defined as the main ones. It is established that the balance between supply and demand for investment resources, and constant desire to achieve this state leads to qualitatively new development of the investment market. The equilibrium point for investment resources and the optimum parameters of its achievements is determined in the construction industry of Ukraine as an example. Based on the study of the factors of influence of the supply and demand function for investment resources in construction, the appropriate corrective indicators are identified. Thus, the indicators that should form the coefficient of correction of the function of the offer of investment resources in construction are defined: the index of investment attractiveness; index of financial freedom; index of freedom of investment; inflation index (consumer price index); official exchange rate of hryvnia to US dollar; the total tax burden on business. For the function of demand for investment resources in construction, the integral indicator of the adjustment should consist of: the index "Working with construction permits"; (component of the index is ease of doing business); investment attractiveness index; index of inflation (consumer price index); the official exchange rate of hryvnia to the US dollar; total tax burden on business. The formation of the functions of supply and demand of investment resources in the construction of Ukraine has been carried out in the form of multiplicative distributive-lag, multivariate nonlinear regression, the effective rate of which is formalized by adapting the Minkowski metric. Optimization of equilibrium values of the factors of shaping supply and demand for investment resources in the construction has been carried out using the structural modeling, which provides the introduction of latent variables for the characteristics of the groups of explicit input indicators, the description the interdependencies between the factors of supply and demand in the form of systems of simultaneous linear pair and multiple regression equations.

Keywords: demand, supply, equilibrium, investment resources, the construction industry.

Introduction. The latest economic conditions and destructive factors that led to the recent financial and economic crises have underlined the need to develop innovative approaches to the revitalization of the investment market of Ukraine. Despite the transition to emergence economy, marketing tools to promote the most business processes remain effective enough. Based on the classic four basic "coordinates" of marketing theory: product, price, place of sale and promotion, it is fair to say that in the framework of the revitalization process of the investment market it is necessary to consider demand, supply and balance between them. This is because in the investment market the product, place sales and promotion in modern conditions have been already clearly defined, and it is very hard to change them at the time, as the price has a primary value. The achievement of the equilibrium point between consumers 

the Assessment of Demand and Supply (Case Study for the Construction Industry)

and donors of investment resources with gradual positive movement ensures the stability of the investment market and the stability of the sectors of the economy. The balance of investment resources in the construction makes it impossible to create financial bubbles and ensures the construction industry has dummy resources. At the same time, it is fair to say that the scientific and methodical tools, which would allow to form a database for effective decision-making in the field of strategic management of the supply and demand of investment resources in the construction industry, is missing. So, the development of the latest techniques of formalization is getting important first, of the supply function of investment resources in the construction, and secondly, of the function of demand for investment resources in the construction; third, of equilibrium in the investment resources in the construction, and, fourth, of the determination of optimal parameters of achievement the equilibrium point between supply and demand of investment resources in the construction. With effective marketing strategy of managing, the demand and supply of investment resources in the construction industry a synergistic effect for the national economy in the form of increased financial resources will be achieved, which will be sent to the economic agents in the construction and the increase in the share of construction sector in GDP of the country.

Analysis of recent research. Many scientists' works are dedicated to theoretical and practical aspects of the research. Thus, the use of marketing tools in order to enhance investment activity is investigated by Granin A. N. (2013). In his research, he considers the maximum amount of marketing determinants of the development of the investment market. Midler E. A., Hovhannisyan N. M. (2013) have a quite different point of view considering the relationship between investment and marketing. The research of the scientists' focuses on defining the role of investment in marketing activities of business entities. The numerous scientific papers are dedicated to the process of analytical formalization of the functions of supply and demand for financial resources; stopping at some of them, we note that classical approaches to constructing these functions are common for such scholars as Basilisco A. J. (2004), Grotkowska G. E. (2008), Yastremsky A. (1998), and others. These authors defend the view that the function of supply and demand for financial resources describes a limited number of relevant indicators.

Probably the greatest number of scientists devoted their works to the features of formation and use of investment resources. So, most scientists, such as Gatezh S.A., Shmagina Y. V. (2010), Moskvin S.(2009), Rumyantseva S. (2009), study the actual problems of formation and prospects of development of investment market in Ukraine, as well as the place of the state in investment processes. In turn, Doroshenko A. G (2017) in his work defines the investment market, as the basic determinant competitiveness of the national economy, and Kobushko I. M. (2012) the most widely explores the impact of the balance of demand and supply on the capital of the state and business entities.

Supporting the idea about high importance of electing a construction sphere as one of the triggers of economic growth in the country can be found in the following works: Asaul A. N., Grahas, V. p. (2007), about certain advantages of investment activity in the construction industry; Gritsenko S.I. (2016) defines preconditions for the development of investment market in Ukraine.

However, none of the scientists has paid sufficient attention to the formation of the evaluation tools of demand and supply of investment resources in the construction industry, finding the equilibrium point between these two parameters and the mechanism of its achievement.

The aim of the article is formation of innovative methods for the assessment of demand, supply and balance for investment resources in construction that will enhance the functioning of the investment market of Ukraine in general.

The main material of the study. Turning to the development of the author's technique of estimation of demand functions and supply of investment resources in the construction in Ukraine, we note that the formulation of an appropriate scientific and methodical approach will include four stages, each of which will consist of several steps.

So, the first phase covers the formation of the input array the performance of required functions. Thus, 
the relevant indicators of the supply function of investment resources in the construction to choose from are proposed as these: household savings (S1); the financial result to the taxation of business entities (S2); the working capital of the entities (S3); capital expenditure of economic entities (S4); capital investment from budgets (S5); the assets of insurance companies (35\% in accordance with regulatory requirements) (S6); the assets of pension funds (10\% in accordance with regulatory requirements) (S7); the assets of credit unions (S8); the assets of the banks (share of long-term loans) (S9); the rate on longterm loans (S10).

The following issues are chosen to characterise the demand for investment resources in the construction: investments in fixed capital in industry and construction (D1); the volume of construction works (D2); capital investment in the construction sector (D3); the financial result for taxing of construction enterprises (D4); the level of profitability of activities in the construction field (D5); the volume of sold production in industry and construction (D6); working capital of construction enterprises (D7); the ratio of square meters of housing per capita in Ukraine by the value of the same indicator in the EU countries (D8); rate on long-term loans (D9); the volume of direct foreign investments in the construction industry (D10). In parallel with the main indicators of characteristics of the supply and demand of investment resources in the construction industry it is also necessary to identify the indicators of adjustment. These indicators characterise the market changes which directly affect each of the selected relevant indicators.

Thus, it is suggested allocating five indicators adjustments features of investment resources in construction: investment attractiveness index; the index of financial freedom; index of freedom of investment; inflation rate (consumer price index); the official exchange rate of hryvnia to the US dollar; the overall tax burden on business and five measures of correction of demand for investment resources in the construction industry: index "Working with construction permits" (part of the index of ease of doing business); the investment attractiveness index;inflation (consumer price index); the official exchange rate of hryvnia to the US dollar; the overall tax burden on business.

Moving to the second phase of implementation of the scientific-methodical approach to estimation of supply and demand of investment resources in the construction, we note that its essence is to reduce all of the input indicators to comparable form. The importance of this stage lies in the fact that the quantitative performance function of supply and demand of investment resources in the construction is only possible through the mathematical transformations of the same measurement indicators.

The implementation of this approach requires a preliminary normalization of input indices using the following formulae:

- for indicators-stimulants:

$$
\widetilde{x_{\imath J}}=\left|1-\frac{x_{i j}}{x_{\max j}}\right|
$$

where $\widetilde{x_{l j}}$ is a normalized value of the $j$-th indicator of the characteristics of the supply (demand) of investment resources in the construction of the i-th year; $x_{i j}$ is the input absolute value of the $j$-th indicator of the characteristics of the supply (demand) of investment resources in the construction of the i-th year; $x_{\max }$ is the maximum possible value of $\mathrm{j}$-th index characteristics of the supply (demand) of investment resources in the construction during the time range;

- for performance-destimulative:

$$
\widetilde{x_{\imath j}}=\left|1-\frac{x_{\operatorname{minj}}}{x_{i j}}\right|
$$

where $x_{\text {minj }}$ is the minimum possible value of the $j$-th indicator of the characteristics of the supply (demand) of investment resources in the construction for the considered time range. 
- for corrective indicators-stimulants:

$$
K_{i l}=\frac{k_{i l}}{1 / m \sum_{l=1}^{m} k_{i l}}
$$

- for corrective indicators destimulative:

$$
K_{i l}=\frac{1 / m \sum_{l=1}^{m} k_{i l}}{k_{i l}}
$$

where $K_{i l}$ is normalized value of I-th indicator of the adjustment to the ask (bid) of investment resources in the construction of the i-th year.

The third stage of the proposed scientific and methodical approach is to calculate the integral indicator of the supply and demand of investment resources in the construction. Practical solution to the problem, it is advisable to carry through the adaptation of the Minkowski metric [14] by forming the utility function as a separate case of this approach.

Taking the above formula normalization into account, the desired integral indicators takes the form:

$$
\begin{aligned}
& S\left(x_{i}\right)=0.1 \cdot\left(\sum_{j=1}^{9}\left|1-\frac{x_{i j}}{x_{\max }}\right|+\left|1-\frac{x_{\min 10}}{x_{i 10}}\right|\right) \cdot \prod_{l=1}^{6} K_{i l} \\
& D\left(x_{i}\right)=0.1 \cdot\left(\sum_{j=1}^{8,10}\left|1-\frac{x_{i j}}{x_{\max }}\right|+\left|1-\frac{x_{\min 9}}{x_{i 9}}\right|\right) \cdot \prod_{l=1}^{5} \mathrm{C}_{i l}
\end{aligned}
$$

where $S\left(x_{i}\right)$ is an integral index of evaluation of the proposal of investment resources in the construction of the i-th year; $D\left(x_{i}\right)$ is an integral index of assessment of the demand for investment resources in the construction of the i-th year; $K_{i l}$ - th index of adjustment of the integral indicator of the characteristics of the demand of investment resources in the construction of the i-th year; $\mathrm{C}_{i l}$-th index of adjustment of integral indicator of the characteristics of the demand of investment resources in the construction of the i-th year.

At the final fourth stage of the proposed scientific and methodical approach it is necessary to conduct the formation of the functions of supply and demand for investment resources in the construction sector as a multiplicative distributive-lag, multi-factor nonlinear regression dependencies. The solution of the problem proposed to be undertaken in several steps, namely:

1. Identification of the lag delay influence of supply factors on the effective indicator, which involves the construction of tables, columns which represented the relative value of the integral indicator of assessment of the supply and demand of investment resources in the construction, consider the time series of the studied factor indicator as well as the time series of this factor increased, shifted by 1,2,5 years. The necessity of this step is actual due to the fact that the influence of factor signs on effective occurs with different time lags.

2. Estimation of the lag delay factor signs from 0 to 5 years from the effective index on the basis of correlation analysis.

3. Defining specification according to each factor of supply and demand of investment resources in the construction with statistical significance (calculation of the student criterion) in case of linear dependencies, and graphical and trend analysis in case of nonlinear dependence.

4. Formation of the general form of the demand function and the supply of investment resources in 
the construction, as the multiplicative distributive-lag, multi-factor nonlinear regression according to:

$$
\begin{aligned}
& S(t)=s_{0} \cdot \prod_{j=1,10} e^{s_{j} \cdot S j(t-t j s)} \cdot \prod_{j=2,9} S j^{s_{j}}(t-t j s) \cdot \prod_{j=3,8} S j^{2 \cdot s_{j}}(t-t j s) \cdot \prod_{j=4}^{7} S j^{s_{j}}(t-t j s) \\
& D(t)=d_{0} \prod_{j=1}^{3} D j^{d_{j}}(t-t j d) \prod_{j=6,8} D j^{d_{j}}(t-t j d) \prod_{j=4,5} D j^{2 \cdot d_{j}}(t-t j d) \cdot \prod_{j=9,10} \ln (D j(t-t j d))^{d_{j}}(8)
\end{aligned}
$$

where $S(t)(\mathrm{D}(t))$ is a function of the supply and demand of investment resources in the construction; $s_{0}, s_{j}, d_{0}, d_{j}$ are the coefficients (constants); $t j s(t j d)$ are lag delay of the j-th indicator of the characteristics of the supply (demand) of investment resources in the construction.

Thus, the above algorithm allows practical calculations on data describing the consumers and donors of investment resources in the construction industry of Ukraine [8] to construct a function of supply and demand of investment resources in the construction in the form of multiplicative distributive-lag, multivariate nonlinear regression. The specified coefficients of regression are calculated by applying the tools of MS Excel "Data Analysis Regression":

$$
\begin{aligned}
& S(t)=e^{-11.655-1.379 \cdot S 1(t-3)} \cdot S 2^{0.061}(t-3) \cdot S 3^{-2 \cdot 0.035}(t) \cdot S 4^{0.084}(t 3) \cdot S 5^{0.256}(t-1) \cdot \\
& \cdot S 6^{0.008}(t-5) \cdot S 7^{-0.486}(t 3) \cdot S 8^{2 \cdot 0.065}(t-4) \cdot S 9^{1.025}(t) \cdot e^{-0.043 \cdot S 10(t)} \\
& D(t)=e^{-584.389} \cdot D 1^{1.336}(t-3) \cdot D 2^{-7.371}(t-3) \cdot D 3^{-4.327}(t-5) \cdot D 4^{-2 \cdot 0.114}(t-4) \cdot D 5^{2 \cdot 0.236}(t-5) \cdot \\
& \cdot D 6^{0.323}(t-2) \cdot(\ln D 7(t-2))^{9.747} \cdot D 8^{174.199}(t-5) \cdot(\ln D 9(t-4))^{-16.299} \cdot(\ln D 10(t))^{-4.459}
\end{aligned}
$$

Thus, the analytical formalization of the functions of supply and demand of investment resources in Ukraine gives the possibility to determine the forecast value of the effective indices depending on ten factor variables. In addition, it is fair to say that the generated function considers the different temporal influence of each factor variable. Also, it is fair to note that the analytical expression for the function of supply and demand of investment resources is the final stage of the preparatory process of finding equilibrium in the investment resources in the construction and identification of their optimal values.

Developing the modelling equilibrium in investment resources in the construction of Ukraine, first, let us analyse the existing situation from 2000 to 2017, in terms of the behaviour of the values of supply and demand for investment resources and their functions. However, before grouping all the necessary data for implementing this phase, we note, that among the indicators of the characteristics of the supply and demand for investment resources in the construction, there is one common factor - the rate on long-term loans. This indicator is a criterion by which it is possible to find the point of intersection of the functions of supply and demand, and therefore the equilibrium point. At the same time, it is also important to formulate a mechanism for optimizing the parameters of achieving this equilibrium state in the future. That is, the rate on long-term loans is a peculiar price for investment resources in the construction of Ukraine, both for the economic agents who form the supply, and the demand for this type from financial resources.

So, let us group the rate of interest rates on long-term loans, the value of the supply of investment resources in construction, the value of demand for investment resources in construction, as well as the difference between demand and supply in Table 1.

Turning to the direct modelling of the equilibrium on investment resources in the construction of Ukraine, we note that, first of all, it is necessary to determine the equilibrium value of the rate on long-term loans. In order to solve this problem, we construct the problem of nonlinear programming and clear it by searching the decision by a simplex method. Thus, the objective function is proposed to select the difference between the functions of the supply and demand for investment resources in construction, which goes for absolute values to zero, that is, in this way we will achieve an equilibrium state between the two 
investigated functions. In turn, the variables of the equation may be considered within the two groups: 1) management variable, which is the value of the rate on long-term loans, which, within the parameters of the characteristics of the sentence has a symbol $S 10$, and within the demand $D 9$. This allows you to record the following equation: $S 10=D 9=X ; 2$ ) indicators of the supply and demand characteristics of investment resources in construction in the form of averages. The above steps are required to bring the non-linear multiple regression to the non-linear pair, namely:

$$
F(S 10=D 9=X)=|S(X)-D(X)| \rightarrow 0
$$

$F(S 10=D 9=X)=\mid e^{-11.655-1.379 \cdot S 1(t-3)} \cdot S 2^{0.061}(t-3) \cdot S 3^{-2 \cdot 0.035}(t) \cdot S 4^{0.084}(t 3) \cdot$ $\cdot S 5^{0.256}(t-1) \cdot S 6^{0.008}(t-5) \cdot S 7^{-0.486}(t 3) \cdot S 8^{2 \cdot 0.065}(t-4) \cdot S 9^{1.025}(t) \cdot e^{-0.043 \cdot X}-e^{-584.389}$. $\cdot D 1^{1.336}(t-3) \cdot D 2^{-7.371}(t-3) \cdot D 3^{-4.327}(t-5) \cdot D 4^{-2 \cdot 0.114}(t-4) \cdot D 5^{2 \cdot 0.236}(t-5) \cdot D 6^{0.323}$. $\cdot(t-2) \cdot(\ln D 7(t-2))^{9.747} \cdot D 8^{174.199}(t-5) \cdot(\ln X(t-4))^{-16.299} \cdot(\ln D 10(t))^{-4.459} \mathrm{I} \rightarrow 0(12)$

Table 1 - Dynamics of the equilibrium characteristics values for investment resources in the construction of Ukraine for 2000-2017 years

\begin{tabular}{|c|c|c|c|c|c|c|c|c|c|}
\hline \multirow{2}{*}{ Indicator } & \multicolumn{9}{|c|}{ Year } \\
\hline & 2000 & 2001 & 2002 & 2003 & 2004 & 2005 & 2006 & 2007 & 2008 \\
\hline $\begin{array}{l}\text { Rate on long-term } \\
\text { loans, \% }\end{array}$ & 16,843 & 16,272 & 15,720 & 15,187 & 14,672 & 14,175 & 13,785 & 13,605 & 14,034 \\
\hline Offer & 1,000 & 0,145 & 0,257 & 0,182 & 0,236 & 0,258 & 0,330 & 0,434 & 0,507 \\
\hline Demand & 0,313 & 0,308 & 0,295 & 0,281 & 0,262 & 0,242 & 0,168 & 0,155 & 0,396 \\
\hline Difference & 0,687 & $-0,164$ & $-0,038$ & $-0,100$ & $-0,026$ & 0,016 & 0,162 & 0,280 & 0,111 \\
\hline $\begin{array}{l}\text { Rate on long-term } \\
\text { loans, \% }\end{array}$ & 16,461 & 11,444 & 10,917 & 12,018 & 11,235 & 12,406 & 12,696 & 10,959 & 9,370 \\
\hline Offer & 0,412 & 0,444 & 0,456 & 0,524 & 0,488 & 0,373 & 0,340 & 0,440 & 0,603 \\
\hline Demand & 0,279 & 0,316 & 0,285 & 0,166 & 0,284 & 1,000 & 0,913 & 0,423 & 0,224 \\
\hline Difference & 0,133 & 0,128 & 0,171 & 0,358 & 0,203 & $-0,627$ & $-0,573$ & 0,016 & 0,380 \\
\hline
\end{tabular}

On the basis of the solution of equation 11, we obtain the equilibrium value of the long-term loan rate, which is identical for both supply function and the demand function for investment resources in construction.

The graphical representation of the solution to problem 8 can be represented by means of Figure 1 , which clearly allows to set the level of equilibrium interest rate on long-term loans, which overlap functions of supply and demand for investment resources in the construction of Ukraine at $12.49 \%$.

Determining the equilibrium value of the rate on long-term loans allows us to establish optimal indicators of the characteristics of supply and demand for investment resources. In other words, it allows to model the optimal values of indicators of the characteristics of supply and demand functions, which will ensure the equilibrium of investment resources in the construction of Ukraine. From the point of view of economic-mathematical modeling, the problem of expressing the equilibrium value of the rate on longterm loans of the equilibrium values of indicators of the supply and demand characteristics of investment resources in construction is raised.

To accomplish the task, it is proposed to conduct a structural modeling of the interdependence of the characteristics of supply and demand characteristics on investment resources in construction. To this end, we introduce latent variables GROUP1, GROUP2, GROUP3, GROUP4, GROUP 5 each of which is characterized by obvious variables that performance characteristics of supply and demand for investment funds (Table 2). 


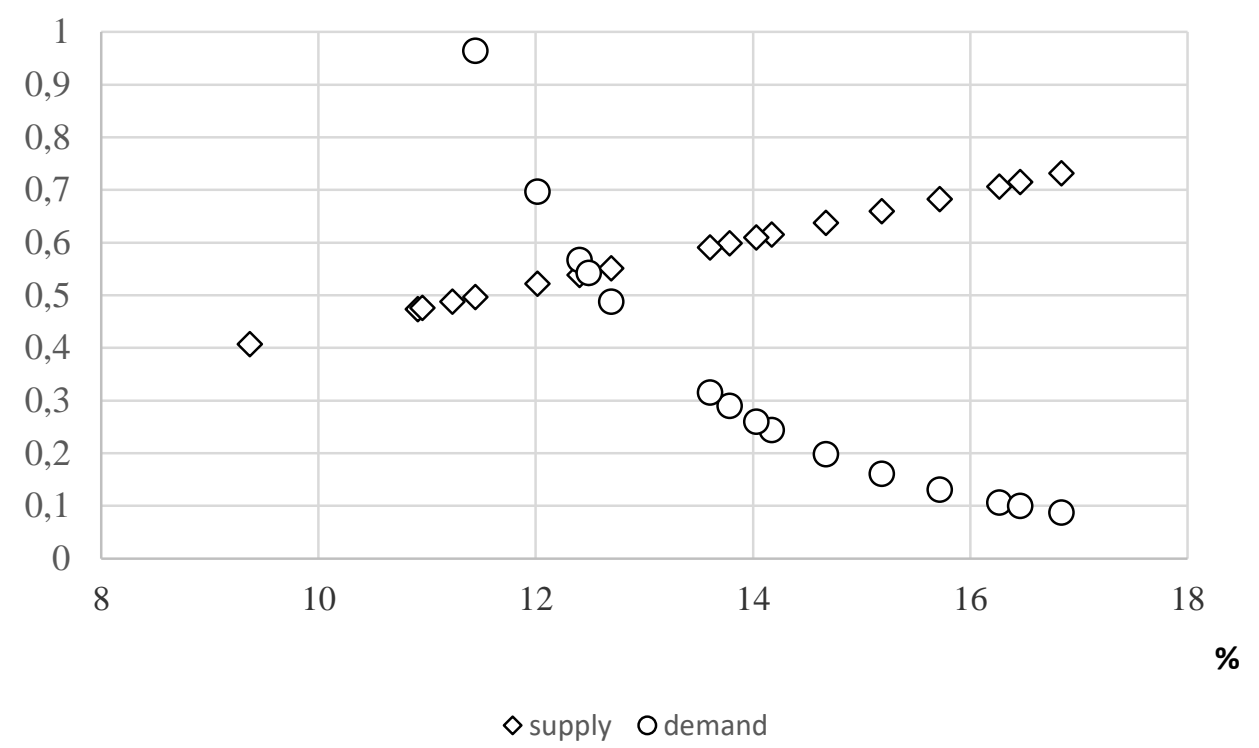

Figure 1 - Graph of the flow of demand and supply on the investment resources on the basis of the balancing rate on long-term loans

Table 2 - Distribution by latent variables of factors of estimation of demand and supply of investment resources in construction

\begin{tabular}{|l|c|l|c|}
\hline \multicolumn{1}{|c|}{ Offer } & Group & \multicolumn{1}{|c|}{ Demand } & Group \\
\hline Savings & 1 & Investments in fixed assets in the construction field & 2 \\
\hline Financial result before tax (profit/loss) & 2 & The volume of executed construction works & 4 \\
\hline Working capital, UAH million & 2 & Capital investment in the construction industry & 2 \\
\hline Capital investment from enterprises & 2 & $\begin{array}{l}\text { Financial result before taxation of construction } \\
\text { enterprises }\end{array}$ & 3 \\
\hline $\begin{array}{l}\text { Capital investment from budgets of all } \\
\text { levels }\end{array}$ & 3 & The level of profitability in the field of construction & 3 \\
\hline Assets of insurers & 4 & The volume of sales in the field of construction & 4 \\
\hline Assets of NPF & 4 & Working capital of construction enterprises & 3 \\
\hline Assets of credit unions, UAH million & 4 & $\begin{array}{l}\text { The ratio of square meters of housing per capita in } \\
\text { Ukraine to the value of a similar indicator in the EU }\end{array}$ & 1 \\
\hline Assets of banks & 4 & Rate on long-term loans & 5 \\
\hline Rate on long-term loans & 5 & $\begin{array}{l}\text { The volume of direct foreign investment in the } \\
\text { construction industry }\end{array}$ & 2 \\
\hline
\end{tabular}

The attribution of indicators of the supply and demand characteristics of investment resources in construction to each of the five selected groups was based on economic logic, namely, the similarity of their economic impact on the performance indicator.

So, on the basis of the grouping, which allows to establish latent variables GROUP1, GROUP2, GROUP3, GROUP4, GROUP5 it is possible to build a table shown in Figure 2 with the tools "Structural Equation Modeling"; package Statistica 10.0. This table contains the coefficients of the structural equation. 
Y. V. Chirichenko, N. O. Fisunenko. Marketing Determinants of the Development of the Investment Market: Innovations in the Assessment of Demand and Supply (Case Study for the Construction Industry)

\begin{tabular}{|c|c|c|c|c|}
\hline & $\begin{array}{l}\text { Estimation of } \\
\text { parameters }\end{array}$ & Standard error & T-statistics & $\begin{array}{c}\text { Probable } \\
\text { level }\end{array}$ \\
\hline (GROUP1)-1->[S1] & $-28,061$ & 75,992 & $-0,369$ & 0,712 \\
\hline \multicolumn{5}{|l|}{$($ DELTA1) $\rightarrow>$ [S1] } \\
\hline (DELTA1)-2-(DELTA1) & 61328,997 & 21195,580 & 2,893 & 0,004 \\
\hline \multicolumn{5}{|l|}{ (GROUP2) $\rightarrow>$ [S2] } \\
\hline (GROUP2)-3->[S3] & 737,091 & 68,344 & 10,785 & 0,000 \\
\hline (GROUP2)-4->[S4] & 55,604 & 0,000 & & \\
\hline \multicolumn{5}{|l|}{ (GROUP3) $->$ [S5] } \\
\hline \multicolumn{5}{|l|}{ (GROUP4)-->[S6] } \\
\hline (GROUP4)-5->[S7] & 0,482 & 0,003 & 154,651 & 0,000 \\
\hline (GROUP4)-6->[S8] & 0,489 & 0,004 & 129,109 & 0,000 \\
\hline (GROUP4)-7->[S9] & 1,987 & 0,170 & 11,685 & 0,000 \\
\hline \multicolumn{5}{|l|}{ (GROUP5)-->[S10] } \\
\hline \multicolumn{5}{|l|}{ (EPSILON1)-->[S2] } \\
\hline \multicolumn{5}{|l|}{ (EPSILON2)- $\rightarrow$ [S3] } \\
\hline \multicolumn{5}{|l|}{ (EPSILON3) $->[S 4]$} \\
\hline \multicolumn{5}{|l|}{$($ EPSILON4) $\rightarrow>$ [S5] } \\
\hline \multicolumn{5}{|l|}{$($ EPSILON5) $\rightarrow->$ S6] } \\
\hline \multicolumn{5}{|l|}{$($ EPSILON6)- $>$ [S7] } \\
\hline \multicolumn{5}{|l|}{ (EPSILON7) $->$ [S8] } \\
\hline \multicolumn{5}{|l|}{ (EPSILON8)-->[S9] } \\
\hline \multicolumn{5}{|l|}{ (EPSILON9)->[S10] } \\
\hline (EPSILON1)-8-(EPSILON1) & 548752,385 & 188220,705 & 2,915 & 0,004 \\
\hline (EPSILON2)-9-(EPSILON2) & 1665203,113 & 971959,720 & 1,713 & 0,087 \\
\hline (EPSILON3)-10-(EPSILON3) & 2309,178 & 4544,497 & 0,508 & 0,611 \\
\hline (EPSILON4)-11-(EPSILON4) & 263,613 & 0,000 & & \\
\hline (EPSILON5)-12-(EPSILON5) & 354,360 & 122,426 & 2,894 & 0,004 \\
\hline (EPSILON6)-13-(EPSILON6) & 0,985 & 1,247 & 0,790 & 0,429 \\
\hline (EPSILON7)-14-(EPSILON7) & 38,352 & 13,370 & 2,868 & 0,004 \\
\hline (EPSILON8)-15-(EPSILON8) & 246580,477 & 84579,826 & 2,915 & 0,004 \\
\hline (EPSILON9)-16-(EPSILON9) & 0,500 & 0,000 & & \\
\hline \multicolumn{5}{|l|}{ (ZETA1)-->(GROUP2) } \\
\hline \multicolumn{5}{|l|}{ (ZETA2)-->(GROUP3) } \\
\hline \multicolumn{5}{|l|}{ (ZETA3)-->(GROUP4) } \\
\hline \multicolumn{5}{|l|}{ (ZETA4)-->(GROUP5) } \\
\hline (ZETA1)-17-(ZETA1) & 31,854 & 25,618 & 1,243 & 0,214 \\
\hline (ZETA2)-18-(ZETA2) & 26,516 & 0,000 & & \\
\hline (ZETA3)-19-(ZETA3) & 392735,183 & 162392,475 & 2,418 & 0,016 \\
\hline (ZETA4)-20-(ZETA4) & 3,135 & 0,000 & & \\
\hline (GROUP1)-21->(GROUP2) & 1,067 & 10,867 & 0,098 & 0,922 \\
\hline (GROUP1)-22->(GROUP3) & 21,168 & 10,145 & 2,087 & 0,037 \\
\hline (GROUP1)-23->(GROUP4) & $-772,306$ & 389,081 & $-1,985$ & 0,047 \\
\hline (GROUP1)-24->(GROUP5) & 6,125 & 8,301 & 0,738 & 0,461 \\
\hline (GROUP2)-25-> (GROUP3) & 8,118 & 7,201 & 1,127 & 0,260 \\
\hline (GROUP2)-26->(GROUP4) & $-215,035$ & 263,245 & $-0,817$ & 0,414 \\
\hline (GROUP2)-27->(GROUP5) & 1,948 & 0,000 & & \\
\hline (GROUP3)-28->(GROUP4) & 23,933 & 0,000 & & \\
\hline (GROUP3)-29->(GROUP5) & $-0,263$ & 0,256 & $-1,029$ & 0,303 \\
\hline (GROUP4)-30 $>>$ (GROUP5) & 0,918 & 0,006 & 152,279 & 0,000 \\
\hline
\end{tabular}

Figure 2 - Results of structural modeling of interdependence of factors of supply of investment resources in construction 
Based on the data obtained in Figure 2 we will construct a system of structural equations:

$$
\left\{\begin{array}{c}
S 1=-28.061 \cdot \text { GROUP } 1+61328.997 \\
\text { S2 }=\text { GROUP } 2+548752.385 \\
S 3=737.091 \cdot \text { GROUP } 2+1665203.113 \\
S 4=55.604 \cdot \text { GROUP } 2+2309.178 \\
\text { S5 }=\text { GROUP } 3+263.613 \\
S 6=\text { GROUP } 4+354.360 \\
S 7=0.482 \cdot \text { GROUP } 4+0.985 \\
S 8=0.489 \cdot \text { GROUP } 4+38.652 \\
S 9=1.987 \cdot \text { GROUP } 4+246580.477 \\
\text { S10 }=\text { GROUP } 5+0.500 \\
\text { GROUP } 2=1.067 \cdot \text { GROUP } 1+31.854 \\
\text { GROUP3 }=21.168 \cdot \text { GROUP } 1+8.118 \cdot \text { GROUP } 2+26.516 \\
\text { GROUP } 4=-772.306 \cdot \text { GROUP } 1-215.036 \cdot \text { GROUP } 2+ \\
+23.933 \cdot \text { GROUP }+392735.183 \\
\text { GROUP } 5=6.125 \cdot \text { GROUP } 1+1.948 \cdot \text { GROUP } 2- \\
-0.263 \cdot \text { GROUP }+0.918 \cdot \text { GROUP }+3.135
\end{array}\right.
$$

where GROUP1, GROUP2, GROUP3, GROUP4, GROUP5 are latent variables of the groups of factors of evaluation of the supply of investment resources in construction.

For the demand for investment resources in the construction of Ukraine, the table with the coefficients of structural equations will take the form of Figure 3. Based on the data in Figure 3, we formalize the system of structural equations:

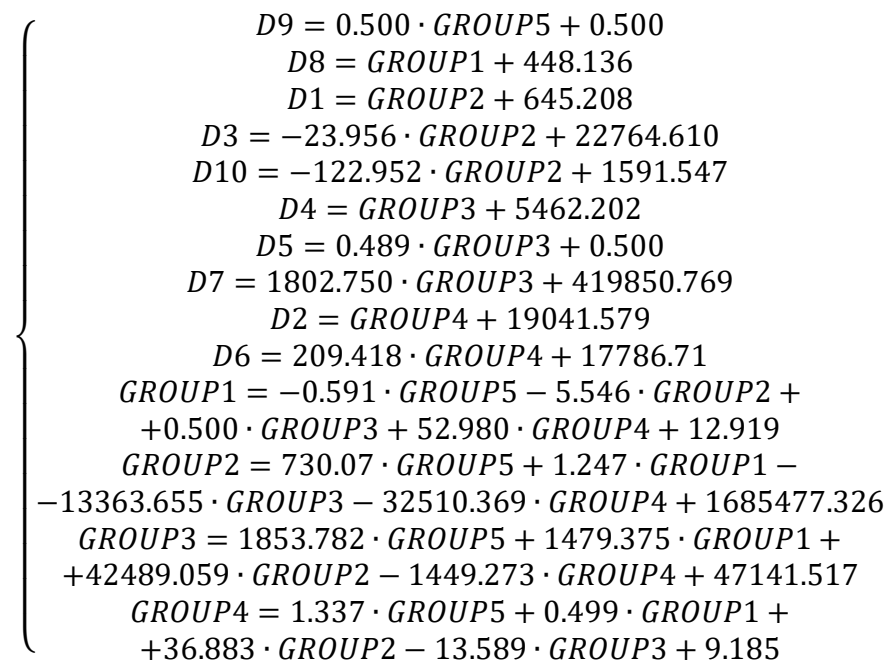

The adequacy of models 9 and 10 is confirmed by the noncentrality indices and the schedule of normalized residues. Thus, in particular, the Stinger-Lind index goes to infinity, Macdonald's index goes to the zero value, while the normalized residues slightly deviate from the red line, which confirms the indicated adequacy of the detected dependencies. 
Y. V. Chirichenko, N. O. Fisunenko. Marketing Determinants of the Development of the Investment Market: Innovations in the Assessment of Demand and Supply (Case Study for the Construction Industry)

\begin{tabular}{|c|c|c|c|c|}
\hline & $\begin{array}{c}\text { Estimation of } \\
\text { parameters }\end{array}$ & Standard error & T-statistics & $\begin{array}{c}\text { Probable } \\
\text { level }\end{array}$ \\
\hline (GROUP5)-1->[D9] & 0,500 & 0,000 & & \\
\hline \multicolumn{5}{|l|}{$(\mathrm{DELTA} 1) \rightarrow[\mathrm{D} 9]$} \\
\hline (DELTA1)-2-(DELTA1) & 0,500 & 0,257 & 1,943 & 0,052 \\
\hline \multicolumn{5}{|l|}{$($ GROUP1) $\rightarrow[$ [D8] } \\
\hline \multicolumn{5}{|l|}{ (GROUP2) $\rightarrow$ [D1] } \\
\hline (GROUP2)-3 $\rightarrow[$ [D3] & $-23,956$ & 75,153 & $-0,319$ & 0,750 \\
\hline (GROUP2) $-4->$ [D10] & $-122,952$ & 49,373 & $-2,490$ & 0,013 \\
\hline \multicolumn{5}{|l|}{$($ GROUP3) $\rightarrow[$ [D4] } \\
\hline (GROUP3)-5->[D5] & 0,489 & 0,000 & & \\
\hline (GROUP3)-6 -> [D7] & 1802,750 & 898,641 & 2,006 & 0,045 \\
\hline \multicolumn{5}{|l|}{$($ GROUP4) $\rightarrow[$ [D2] } \\
\hline (GROUP4)-7 $\rightarrow$ [D6] & 209,418 & 154,392 & 1,356 & 0,175 \\
\hline \multicolumn{5}{|l|}{ (EPSILON1) $\rightarrow[$ [D8] } \\
\hline \multicolumn{5}{|l|}{$($ EPSILON2) $\rightarrow[D 1]$} \\
\hline \multicolumn{5}{|l|}{$($ EPSILON3) $\rightarrow[\mathrm{D} 3]$} \\
\hline \multicolumn{5}{|l|}{$($ EPSILON4) $\rightarrow[D 10]$} \\
\hline \multicolumn{5}{|l|}{$($ EPSILON5) $\rightarrow$ [D4] } \\
\hline \multicolumn{5}{|l|}{$($ EPSILON6) $\rightarrow[$ [D5] } \\
\hline \multicolumn{5}{|l|}{ (EPSILON7) $\rightarrow[$ [D7] } \\
\hline \multicolumn{5}{|l|}{$($ EPSILON8) $\rightarrow[$ [D2] } \\
\hline \multicolumn{5}{|l|}{$($ EPSILON9) $\rightarrow[$ D6] } \\
\hline (EPSILON1)-8-(EPSILON1) & 448,130 & 0,000 & & \\
\hline (EPSILON2)-9-(EPSILON2) & 645,208 & 221,317 & 2,915 & 0,004 \\
\hline (EPSILON3)-10-(EPSILON3) & 22764,610 & 7816,190 & 2,912 & 0,004 \\
\hline (EPSILON4)-11-(EPSILON4) & 1591,547 & 0,000 & & \\
\hline (EPSILON5)-12-(EPSILON5) & 5462,202 & 1873,542 & 2,915 & 0,004 \\
\hline (EPSILON6)-13-(EPSILON6) & 0,500 & 0,000 & & \\
\hline (EPSILON7)-14-(EPSILON7) & 419850,769 & 359541,122 & 1,168 & 0,243 \\
\hline (EPSILON8)-15-(EPSILON8) & 19041,579 & 6531,211 & 2,915 & 0,004 \\
\hline (EPSILON9)-16-(EPSILON9) & 17786,711 & 6312,768 & 2,818 & 0,005 \\
\hline \multicolumn{5}{|l|}{$($ ZETA1) $\rightarrow$ (GROUP1) } \\
\hline \multicolumn{5}{|l|}{$($ ZETA2) $\rightarrow$ (GROUP2) } \\
\hline \multicolumn{5}{|l|}{ (ZETA3) $\rightarrow$ (GROUP3) } \\
\hline \multicolumn{5}{|l|}{ (ZETA4) $\rightarrow($ (GROUP4) } \\
\hline (ZETA1)-17-(ZETA1) & 12,919 & 0,000 & & \\
\hline (ZETA2)-18-(ZETA2) & 1685477,326 & 26690734,777 & 0,063 & 0,950 \\
\hline (ZETA3)-19-(ZETA3) & 47141,517 & 0,000 & & \\
\hline (ZETA4)-20-(ZETA4) & 9,185 & 0,000 & & \\
\hline (GROUP5)-21->(GROUP1) & $-0,591$ & 17,028 & $-0,035$ & 0,972 \\
\hline (GROUP5)-22 $\rightarrow$ (GROUP2) & 730,070 & 9101,403 & 0,080 & 0,936 \\
\hline (GROUP5)-23 $\rightarrow$ (GROUP3) & 1853,782 & 14446,478 & 0,128 & 0,898 \\
\hline (GROUP5)-24->(GROUP4) & 1,337 & 7,097 & 0,188 & 0,851 \\
\hline (GROUP1)-25 $\rightarrow$ (GROUP2) & 1,247 & 0,000 & & \\
\hline (GROUP1)-26->(GROUP3) & 1479,375 & 0,000 & & \\
\hline (GROUP1)-27->(GROUP4) & 0,499 & 0,000 & & \\
\hline (GROUP2)-28 $\rightarrow$ (GROUP1) & $-5,546$ & 0,000 & & \\
\hline (GROUP2)-29->(GROUP3) & 42489,059 & 0,000 & & \\
\hline (GROUP2)-30->(GROUP4) & 36,883 & 0,000 & & \\
\hline (GROUP3)-31 $\rightarrow$ (GROUP1) & 0,500 & 0,000 & & \\
\hline (GROUP3)-32->(GROUP2) & $-13363,655$ & 0,000 & & \\
\hline (GROUP3)-33 $\rightarrow$ (GROUP4) & $-13,589$ & 6,354 & $-2,139$ & 0,032 \\
\hline (GROUP4)-34 $\rightarrow$ (GROUP1) & 52,980 & 0,000 & & \\
\hline (GROUP4)-35 $\rightarrow$ (GROUP2) & $-32510,369$ & 0,000 & & \\
\hline (GROUP4)-36 $\rightarrow$ (GROUP3) & $-1449,273$ & 0,000 & & \\
\hline
\end{tabular}

Figure 3 - Results of structural modeling of the interdependence of demand factors on investment resources in construction 
Thus, having established that the obtained structural equations are adequate, their decision becomes actual. Thus, taking into account the equilibrium value of the long-term loans rate at the level of $12.49 \%$ of the solution of the resulted equations, one can determine the optimal values of the parameters of the supply and demand for investment resources in construction and group them in Table 3.

Thus, based on the analysis of data in Table 3, it is fair to note that in order to bring the investment supply function in the construction of Ukraine to an equilibrium state, it is important to direct the investment policy of business entities and the state to reduce savings, that is, the activation of instruments for the transformation of financial resources from banking to the real sector of the economy in the form of investment in construction. The need to reduce the assets of insurers and assets of credit unions in order to achieve the balancing of the offer function with the function of demand for investment resources can be explained by the fact that the proportion of asset data of financial intermediaries, which is sent to construction, is not significant, and therefore their effectiveness offsets. Reduction of capital investments from enterprises in order to achieve a balance on investment resources in construction can be explained by the fact that in the development of economic entities capital investments, in modern conditions, do not go for construction but for the purchase of equipment.

All other indicators, within the characteristics of the offer of investment resources in construction, namely the financial result before taxation, working capital, capital investments from budgets of all levels, assets of NPF and assets of banks, need to be increased to achieve a balance on investment resources in construction at the expense of a well-considered organization business processes, directly, economic entities, and the creation of appropriate conditions for the conduct of economic and investment activity by the state authorities.

Table 3 - Results of the determination of equilibrium values of indicators of the supply and demand characteristics of investment resources in construction, depending on the equilibrium value of the rate on long-term loans

\begin{tabular}{|c|c|c|c|c|c|}
\hline Indicators of demand & $\begin{array}{c}\text { Optimum } \\
\text { value }\end{array}$ & $\begin{array}{c}\text { Average } \\
\text { value }\end{array}$ & Offer rate & $\begin{array}{c}\text { Optimum } \\
\text { value }\end{array}$ & $\begin{array}{c}\text { Average } \\
\text { value }\end{array}$ \\
\hline 1 & $\mathbf{2}$ & $\mathbf{3}$ & $\mathbf{4}$ & $\mathbf{5}$ & $\mathbf{6}$ \\
\hline $\begin{array}{c}\text { Investments in fixed assets } \\
\text { in the field of construction, } \\
\text { UAH million }\end{array}$ & 645,2 & 6174,4 & Savings, UAH million & 22993,6 & 60779,9 \\
\hline $\begin{array}{c}\text { Volume of executed } \\
\text { construction works, UAH } \\
\text { million }\end{array}$ & 19094,1 & 50375,0 & $\begin{array}{c}\text { Financial result } \\
\text { before tax (profit / } \\
\text { loss), UAH million }\end{array}$ & 550241,9 & 5065,2 \\
\hline $\begin{array}{c}\text { Capital investment in the } \\
\text { construction industry, UAH } \\
\text { million }\end{array}$ & 22764,6 & 40682,9 & $\begin{array}{c}\text { Working capital, UAH } \\
\text { million }\end{array}$ & 2763123,5 & 1315433,0 \\
\hline $\begin{array}{c}\text { Financial result before } \\
\text { taxation of construction } \\
\text { enterprises, UAH million }\end{array}$ & 5462,4 & $-4655,6$ & $\begin{array}{c}\text { Capital investment } \\
\text { from enterprises, } \\
\text { UAH million }\end{array}$ & 85133,1 & 116373,1 \\
\hline $\begin{array}{c}\text { Level of profitability in the } \\
\text { field of construction, \% }\end{array}$ & 0,6 & 0,6 & $\begin{array}{c}\text { Capital investment } \\
\text { from budgets of all } \\
\text { levels, UAH million }\end{array}$ & 41300,7 & 16573,9 \\
\hline $\begin{array}{c}\text { Volume of sales in the field } \\
\text { of construction, UAH million }\end{array}$ & 28783,6 & 98114,6 & $\begin{array}{c}\text { Assets of insurers, } \\
\text { UAH million. }\end{array}$ & 154,5 & 8225,3 \\
\hline $\begin{array}{c}\text { Working capital of } \\
\text { construction enterprises, } \\
\text { UAH million }\end{array}$ & 420220,9 & 91520,8 & $\begin{array}{c}\text { Assets of NPF, UAH } \\
\text { million }\end{array}$ & 244,3 & 96,5 \\
\hline
\end{tabular}


Y. V. Chirichenko, N. O. Fisunenko. Marketing Determinants of the Development of the Investment Market: Innovations in the Assessment of Demand and Supply (Case Study for the Construction Industry)

\begin{tabular}{|c|c|c|c|c|c|}
\hline 1 & $\mathbf{2}$ & $\mathbf{3}$ & $\mathbf{4}$ & $\mathbf{5}$ & $\mathbf{6}$ \\
\hline $\begin{array}{c}\text { The ratio of square meters } \\
\text { of housing per capita in } \\
\text { Ukraine to the value of a } \\
\text { similar indicator in EU } \\
\text { countries, } \%\end{array}$ & 60,1 & 53,5 & $\begin{array}{c}\text { Assets of credit } \\
\text { unions, UAH million }\end{array}$ & 210,5 & 2442,5 \\
\hline Rate on long-term loans, \% & 12,5 & 13,4 & $\begin{array}{c}\text { Assets of banks, } \\
\text { UAH million }\end{array}$ & 245569,4 & 181893,0 \\
\hline $\begin{array}{c}\text { Volume of direct foreign } \\
\text { investments into the } \\
\text { construction industry, UAH } \\
\text { million }\end{array}$ & 1591,6 & 9975,1 & $\begin{array}{c}\text { Rate on long-term } \\
\text { loans, } \%\end{array}$ & 12,5 & 13,4 \\
\hline
\end{tabular}

Demand for investment resources in the construction sector is much larger than the supply, so indicators of the characteristics of the demand function need a significant reduction in order to achieve its equilibrium point. The exception in the general trend of behaviour of indicators of demand for investment resources in construction are the working capital of construction enterprises and the ratio of square meters of housing per capita in Ukraine to the value of a similar indicator in the EU. This is quite logical, since working capital is always not enough for construction companies, and the percentage of housing stock for a long time will not meet the European standards.

In addition, it is fair to note that in order to achieve the equilibrium of investment resources in construction, the long-term rate of $12.5 \%$ is to be respected, which is $7 \%$ less than its average for 2000 2017 , that is, the price of borrowed funds in the long-term period should not exceed $13 \%$.

Conclusion. Thus, the relevant indicators of supply and demand for investment resources in the construction of Ukraine were established in this research. Thus, the function of proposing investment resources in the field of construction was offered to describe by the following factors: household savings; financial result before taxation of business entities; working capital of economic entities; capital investments of business entities; capital investment from budgets; assets of insurance companies; assets of non-state pension funds; assets of credit unions; assets of banks; rate on long-term loans. In turn, the demand function for investment resources in construction is shaped by the following indicators: investment in fixed assets in the field of construction; volume of executed construction works; capital investment in the construction industry; financial result before taxation of construction enterprises; level of profitability in the field of construction; the volume of sales in the field of construction; working capital of construction enterprises; the ratio of square meters of housing per capita in Ukraine to the value of a similar indicator in the EU; the volume of direct foreign investment in the construction industry; rate on long-term loans. Based on the study of the factors of influence of the supply and demand function for investment resources in construction, the appropriate corrective indicators are identified. Thus, the indicators that should form the coefficient of correction of the function of the offer of investment resources in construction are defined: the index of investment attractiveness; index of financial freedom; index of freedom of investment; inflation index (consumer price index); official exchange rate of hryvnia to US dollar; the total tax burden on business. For the function of demand for investment resources in construction, the integral indicator of the adjustment should consist of: the index "Working with construction permits"; (component of the index is ease of doing business); investment attractiveness index; index of inflation (consumer price index); the official exchange rate of hryvnia to the US dollar; total tax burden on business. The scientific-methodical approach to formalizing the functions of supply and demand for investment resources in construction is developed, which includes the following stages: 1) normalization of the input mass of statistical data and corrective indicators; 2) calculation of the integral indicator of the supply or demand for investment 
resources in construction through the adaptation of the metric of Minkowski; 3) the formalization of the functions of the supply or demand for investment resources in construction as multiplicative distributivelag multifactorial nonlinear regression dependencies. The equilibrium value of the interest rate on longterm loans is determined at $12.5 \%$, with the help of constructing a non-linear programming problem and we solve it by finding the decision by a simplex method. The simulation of the optimal values of the indicators of the characteristics of supply and demand functions has been made, using the "Structural Simulation Modeling" toolkit of Statistica 10.0, which would ensure the achievement of the equilibrium on investment resources in the construction of Ukraine, on the basis of which it has been established that the characteristics of the demand function need a significant reduction in order to achieve the equilibrium point. It is substantiated that the reason for the need for these actions is that demand for investment resources in the field of construction in Ukraine is much larger than the supply.

Subsequent studies are aimed at identifying the most effective state tools for adjusting the parameters of forming the equilibrium point of cross-sectional demand and proposing investment resources in the construction of Ukraine.

"Supply, Demand, and Market Equilibrium". Retrieved from: http://www.egreene.k12.

Asaul A.N., Grahov V.P(2007). Integrativnoe upravlenie v investicionno-stroitelnoy cfere. [Integrative management in the investment and construction sector]. / pod redakciey Zaslujennogo stroitelya RF Asaula A.N. - under the editorship of the Honored Builder of the Russian Federation A. N. Asaula. 248.

Basilinska O. I (2004). Microeconomica: Navchalniy posibnik. [Microeconomics: Textbook]. Kiev: Centr navchalnoi literature, 351, [in Ukrainian].

Blank I. A. (2001). Osnovi investicionnogo menegmenta. [Fundamentals of Investment Management]. Kiev: Elha-N. [in Rassian].

Gatezh SA, Shmagina Yu.V . Problemi ta perspective rozvitku investiciynoujnogo rinku v Ukraine. [Problems of formation and prospects of development of the investment market in Ukraine]. Retrieved from: http://www.rusnauka.com/2_ANR_2010/Economics/4_57537.doc.htm

Heyets V.M. (2006). Nestabilnist ta economichne zrostannya. [Instability and economic growth]. (p. 344). [in Ukrainian].

Granin A.N. (2013). Marketing investiciy [Investment marketing]. (№ 1). (pp.185-189). Retrieved from: http://nbuv.gov.ua/jpdf/drep_2013_1_39.pdf

Gritsenko, S.I. (2016). Rozvitok investiciynouj rinku v Ukraine. [Development of the investment market in Ukraine]. Proceedings from MIIM: Mizhnarodna naukovo-tekhychna konferentsiia-International Scientific and Technical Conference. (pp.56-57). Mariupol. [in Ukrainian].

Grontkovskaya G. E. (2008). Microeconomika. [Microeconomics]. Practicum:Navchalniy posibnik. Kiev: Centr navchalnoi literature, (Vol. 2), 418, [in Ukrainian].

Derjavna Slujba Statistiki. [State Statistics Service Ukraine]. Retrieved from: http://www.ukrstat.gov.ua/

Dickman L. G. (1998). Organizaciya I planuvannya budivelnogo virobnictva. [Organization and planning of construction production]. Kiev: Visha shkola.(p.588). [in Ukrainian].

Doroshenko O.H. (211). Rozvitok investiciynouj rinku - shlyah do pidvischennya konkurentnospromojnosti. [The development of an investment market - a way to increase competitiveness]. Retrieved from: file:///C:/ Downloads/development-of-the-investmentmarket-is-a-path-to-the-improvement-of-the-competitiveness pdf

Kirichok T.Yu (2013). Alhoritm rozvyazannya bagatokriterialnoi zadachi viboru pokaznika znoshuvannya banknot za dopomogoyu funkcii corisnosti. [Algorithm for solving the multicriterial problem of choosing the indicator of banknote wear using the utility function.]. Naukovi visti NYUU «KPI». (Vol.1), 68-75, [in Ukrainian].

Kobushko I. M. (2012). Strategia rozvitku investiciynogo rinku: teoretichni zasadi ta vitchiznyani realii. [Strategy of investment market development: theoretical foundations and national realities]. monografia. [monograph]. Sumy:Sumskiy Derjavniy Universitet, 517, [in Ukrainian].

Midler E.A., Hovhannisyan N. M. (2013). Investicii v aspekte marketinga: rinochnaya priroda, specifika marketingovih resheniy. [Investments in the aspect of marketing: market nature, specific marketing decisions]. Retrieved from: http://www.journalnio.com/index.php?option=com_content\&view=frontpage\&ltemid $=1$

Moskvin, S. (2009). Investiciynij rinok Ukraine: peredumovi ta perspective formuvannya u konteksti svitovoi ta finansovoi krizi. [Investment Market of Ukraine: Preconditions and Problems of Formation in the Context of the Global Financial Crisis]. (№3). (pp.812). [in Ukrainian].

Nort D. (1997). Instituti, institucionalnie ismeneniya i funkcionsrovanie economici. [Institutions, institutional changes and the functioning of the economy]. Moskva: Nachala. (p. 180). [in Rassian]. 
Y. V. Chirichenko, N. O. Fisunenko. Marketing Determinants of the Development of the Investment Market: Innovations in the Assessment of Demand and Supply (Case Study for the Construction Industry)

Rumyantseva S. Misce Ukraini na investiciynomu rinku (2009). [Place of Ukraine in the investment market]. Securities of Ukraine. (№16). (pp.14-15). [in Ukrainian].

Shreibar A. K. (1987). Organizaciya I planuvannya budivelnogo virobnictva. [Organization and planning of construction production]. Kiev: Visha shkola.(p.368). [in Ukrainian].

Fisher S. (2001). Economica. [Economics]. Moskva: Delo. (Vol.2). (p.864). [in Ukrainian].

Socoluk K. U. (2013). Sutisna harakteristika ponyat «investicii» ta «investiciyni resursi». [Essential description of the concepts of "investment" and "investment resources"]. monografia. [monograph]. Uman. (pp. 154-159). [in Ukrainian].

Yastremsky O. (1998). Ocnovi microeconomiki. [Basics of microeconomics]. Kiev: Znannya, 674. [in Ukrainian].

Ю. В. Чириченко, д.е.н., професор, Університет митної справи та фінансів (Дніпро, Україна);

H. О. Фісуненко аспірант, Університет митної справи та фінансів (Дніпро, Україна).

Маркетингові детермінанти розвитку інвестиційного ринку: інновації в оцінюванні попиту та пропозиції (на прикладі галузі будівництва).

Стаття присвячена розвитку методичних засад дослідження базових маркетингових детермінант розвитку інвестиційного ринку - попиту та пропозиції, досягнення рівноваги між якими забезпечує стабільний розвиток ринкової кон'юнктури. На прикладі будівельної галузі України розрахована точка рівноваги, при якій попит на інвестииійні ресурси дорівнює їх пропозиції, ідентиффіковані оптимальні параметри її досягнення. На основі дослідження фракторів впливу на функції пропозиції та попиту на інвестиційні ресурси в будівництві емпірично встановлено, що функція пропозиції на досліджуваному сегменті інвестиційного ринку має бути скоригована на індекси інвестииійної привабливості, фрінансової свободи, свободи інвестицій, інфрляиії (індекс споживчих цін), а також офріційний курс гривні до долара США та загальне податкове навантаження на бізнес. Коригуючими параметрами для функиії попиту на інвестиційні ресурси в будівництв визначено: складова індексу легкість ведення бізнесу, яка характеризує легкість отримання дозволів на будівництво, індекси інвестиційної привабливості та інфрляції (індекс споживчих цін), офріційний курс гривні до долара США та загальне податкове навантаження на бізнес. Для моделювання ффункцій попиту та пропозиції інвестииійних ресурсів в будівництві побудовано мультиплікативну дистрибутивно-лагову багатофракторну нелінійну регресійну залежність, результуючий параметр якої формалізовано за допомогою адаптації метрики Мінковського. Розрахунок рівноважних значень факторів формування пропозиції і попиту на інвестиційні ресурси у будівниитві здійснено за допомогою структурного моделювання, яке передбачає введення латентних змінних для характеристики груп явних вхідних показників, опису взаємозалежностей між фракторами попиту і пропозиції у вигляді систем одночасних лінійних парних та множинного регресійних рівнянь.

Ключові слова: маркетингові детермінанти, попит, пропозиція, рівновага, інвестиційні ресурси, будівельна галузь. 